\title{
ANTITRUST ANALYSIS OF TYING ARRANGEMENTS
}

\author{
JAY PIL CHOI
}

CESIFO WORKING PAPER NO. 1336

CATEGORY 9: INDUSTRIAL ORGANISATION

NOVEMBER 2004

Presented at CESifo Venice Summer Institute, Workshop on

RECENT DEVELOPMENTS IN ANTITRUST ANALYSIS, JULy 2004

\footnotetext{
An electronic version of the paper may be downloaded

- from the SSRN website:

www.SSRN.com

- from the CESifo website:

www.CESifo.de
} 


\title{
ANTITRUST ANALYSIS OF TYING ARRANGEMENTS
}

\begin{abstract}
Tying arrangements recently have been a major and contentious issue in many high profile antitrust cases in the US and Europe. Examples include the Microsoft case, the Visa and MasterCard case, and the proposed GE/Honeywell merger to name a few. This paper conducts a selective review of the recent developments in the analysis of tying arrangements. It also discusses relevant antitrust cases concerned with tying arrangements in light of recent theoretical advances in this area.
\end{abstract}

JEL Code: K210, L1.

\author{
Jay Pil Choi \\ Department of Economics \\ Michigan State University \\ East Lansing, MI 48824 \\ USA \\ choijay@msu.edu
}




\section{Introduction}

Tying arrangements recently have been a major and contentious issue in many high profile antitrust cases in the US and Europe. Examples include the Microsoft case, the Visa and MasterCard case and the proposed GE/Honeywell merger. More specifically, the Microsoft case in the US was concerned with bundling of the dominant Windows operating system with Internet Explorer, while the bundling of the operating system and Media Player was an issue in the European case. ${ }^{1}$ The Visa and MasterCard case concerned with tying of debit and credit cards. The case was settled with the two card associations agreeing to pay \$2 billion and \$1 billion, respectively, to a class of merchants and to lower their interchange fees. In the GE/Honeywell case, one of the main issues raised by the proposed merger concerned the possibility of "bundling" and its likely impact on competition in the markets for jet aircraft engines and avionics. ${ }^{2}$ The aim of this paper is to review recent developments in the antitrust analysis of tying arrangements and discusses relevant cases concerned with tying arrangements in light of recent theoretical advances in this area.

It is well documented that tying arrangements can serve many purposes and numerous theories have been proposed to explain the motives for the practice and to find the ensuing anti-trust and welfare implications. The most prominent view is that they serve as a vehicle for price discrimination. Papers in this tradition start with Stigler (1963) and include Adams and Yellen (1976), and Schmalensee (1984) among others. They demonstrated that bundling can increase profit even in the absence of cost advantages to

\footnotetext{
${ }^{1}$ The U.S. Department of Justice and Microsoft reached a settlement with Microsoft in November 2001. The settlement agreement contains no provision for forced unbundling. In the European case, the European Union ruled that Microsoft is guilty of abusing the "near-monopoly" of its Windows PC operating system and fined it a record 497 million euros ( $\$ 613$ million). The case is being appealed by Microsoft.

${ }^{2}$ Another main issue that proved to be the stumbling block in the remedy negotiations between the merging parties and the Commission was the role and competitive implications of GECAS, GE's aircraft leasing and financing arm. The proposed merger was blocked by the European Commission in 2001 and the case is under appeal in the Court of First Instance of the European Union as of this writing.
} 
providing goods in combination or interdependency in demand for the component products. ${ }^{3}$ A variation on this theme is the metering argument in which the purchase of an indivisible machine is accompanied by the requirement that all complementary variable inputs be purchased from the same company. By marking-up the variable inputs above marginal cost, the seller can price discriminate against intense users of the machine with the sale of variable inputs as a metering or monitoring device for the intensity of the machine usage. Other explanations given in this literature include monitoring the cheating on a cartel price, evasion of price controls, protection of goodwill reputation, economies of joint sales, etc. ${ }^{4}$

The anti-competitive role of tying or bundling exemplified by the so-called "leverage theory" is more controversial. According to the leverage theory, a multi-product firm with monopoly power in one market can monopolize another market that otherwise would have been competitive by using the leverage provided by the market power in the first market. By foreclosing sales in the second market, tying provides the mechanism to accomplish this. However, the logic of the theory has been criticized and subsequently dismissed by a number of authors from the University of Chicago school such as Bowman, Posner, and Bork who have argued that the use of leverage to affect the market structure of the tied good (second) market is impossible. It was not until Whinston (1990) that the leverage theory was resuscitated with its first formal treatment. Since then, the theory has been refined and extended in several directions. Recent high profile cases of tying mentioned above also

\footnotetext{
${ }^{3}$ More general conditions for the optimality of bundling are provided in McAfee, McMillan and Whinston (1989). They show that bundling is always optimal when reservation values are independently distributed in the population of consumers. Recently, the Adams-Yellen framework has been generalized to allow the goods to be substitutes and complements. For instance, Lewbel (1985) demonstrates that complementarity is neither necessary nor sufficient to make bundling optimal.

${ }^{4}$ For a comprehensive review of reasons for tying, see Nalebuff (2003)
} 
rekindled the interest in the antitrust analysis of tying and spawned a new line of research. This paper focuses on recent developments in this area.

The rest of the paper is organized in the following way. Section 2 describes the leverage theory of tying and the Chicago school criticism of its implausibility. This was largely responsible for the replacement of leverage by price discrimination in the theory of tying before the leverage theory was revived by Whinston (1990). The Chicago school's contribution lies in revealing serious logical flaws in the early analysis of leverage and helping delineate conditions under which leverage theory does not apply. Section 3 presents the contribution of Whinston (1990) who demonstrated that the Chicago school arguments have limitations and can break down in certain cases. In particular, he argues that the Chicago school argument hinges crucially on the assumption that "the tied good market has a competitive, constant returns-to-scale structure." ${ }^{5}$ If scale economies exist and the structure of the tied good market is oligopolistic, tying can be an effective strategy for a monopolist to extend monopoly power to the tied good market by inducing exit by the rival firms. I also describe subsequent work that identifies further conditions under which the Chicago school arguments may not hold. Section 4 describes models of tying that incorporate incentives to innovate. This literature demonstrates that even in the absence of exit by the rival firm (hence, no changes in the market structure in the tied good market), tying can be a profitable strategy via its long-term effects on competition through innovation. Section 5 discusses tying in the context of merger analysis in complementary markets. Section 6 discusses tying in the so-called two-sided markets that are characterized by inter-group network externalities. Section 7 concludes by discussing antitrust policy implications.

\footnotetext{
${ }^{5}$ Whinston (1990), p. 838.
} 


\section{The Leverage Theory of Tying and the Chicago School Criticism}

The key intellectual rationale for the historically harsh treatment of tying arrangements by the courts in the US has been the so-called "leverage theory." According to the leverage theory of tying, a multiproduct firm with monopoly power in one market can monopolize a second market using the leverage provided by its monopoly power in the first market. The theory, however, came under attack and was largely discredited as a result of criticisms originating in the Chicago School (see e.g. Bowman 1957, Posner 1976, Bork 1978). ${ }^{7}$

The Chicago school criticism can be explained by the following simple model. Consider two independent products, A and B. They are unrelated in the sense that they can be consumed independently and their values to consumers are independent of whether they are consumed separately or together. ${ }^{8}$ Consumers, whose total measure is normalized to 1 , are assumed to be identical and have a unit demand for each product valued at $\mathrm{v}_{\mathrm{A}}$ and $\mathrm{v}_{\mathrm{B}}$, respectively. To focus on the strategic motive for bundling, I assume that there is no cost advantage or disadvantage associated with bundling. The market for product A is monopolized by firm 1 with unit production cost of $c_{A}\left(<v_{A}\right)$. It is assumed that entry into market $\mathrm{A}$ is not feasible. Firm 1 may have a patent or have an installed base that makes entry unprofitable in the presence of network externalities (Farrell and Saloner, 1986). The market for product $\mathrm{B}$, however, is served by two firms, firm 1 and firm 2, who engage in Bertrand competition. For simplicity, product B is assumed to be homogeneous. Unit

\footnotetext{
${ }^{6}$ The leading case is Motion Pictures Patents Co. v. Universal Film Manufacturing Co., 243 U.S. 502 (1917). Other cases include International Salt v. U.S., 332 U.S. 392 (1947) and Northern Pacific Railway Co. v. U.S., 356 U.S. 1 (1958).

${ }^{7}$ Bowman, for instance, claims that "leveraging, in a word, is no more plausible than lifting oneself by ones bootstraps." These arguments, often associated with the University of Chicago oral tradition, are traceable to Aaron Director.

${ }^{8}$ The Chicago school criticism applies equally to the case of complementary products. See Whinston (2001) for more details.
} 
production costs for product $\mathrm{B}$ are given by $\mathrm{c}_{\mathrm{B} 1}$ and $\mathrm{c}_{\mathrm{B} 2}$ for firm 1 and firm 2, respectively. Both firms are already in the market and have paid sunk costs of entry, if there are any. ${ }^{9}$ In such a case of no exclusion of the rival firm, tying is always a weakly dominated strategy if the production cost of each firm is given and cannot be altered. ${ }^{10}$ To see this, I consider the following two-stage game.

In the first stage, firm 1 (the monopolistic supplier of product A) decides whether or not to bundle the two products. A price game ensues in the second stage with the bundling decision in the previous stage as given. The timing assumption reflects the fact that the bundling decision through product design is a longer term decision that cannot be easily modified as compared to the price decision. The outcomes are described below and depend on each firm's bundling decision in the first stage.

\subsection{No Bundling}

If the two products are not bundled, they can be analyzed independently. With the assumption of identical consumers and rectangular demand, firm 1 can extract the whole consumer surplus in market $A$ and have profits of $\left(v_{A}-c_{A}\right)$. In market $B$, the low cost producer serves the whole market at the price of $\max \left(\mathrm{c}_{\mathrm{B} 1}, \mathrm{c}_{\mathrm{B} 2}\right)$. Thus, firm 1 will have the profit of max $\left[\mathrm{c}_{\mathrm{B} 2}-\mathrm{c}_{\mathrm{B} 1}, 0\right]$ in market $\mathrm{B}$. Thus, the overall profit for the monopolist is given by

$$
\Pi_{1}=\left(\mathrm{v}_{\mathrm{A}}-\mathrm{c}_{\mathrm{A}}\right)+\max \left[\mathrm{c}_{\mathrm{B} 2}-\mathrm{c}_{\mathrm{B} 1}, 0\right]
$$

\subsection{Bundling}

\footnotetext{
${ }^{9}$ Thus, entry and exit are not issues in this model. This turns out to be an important assumption, as explained in section 3 .

${ }^{10}$ This result also holds for the case of complementary products. See Choi (1996) and Farrell et al. (1998).
} 
Suppose that the monopolist bundles product $\mathrm{A}$ and $\mathrm{B}$ and charges the price of $\mathrm{P}$ for the bundled product. In this case, consumers have two choices. The first option is to buy the bundled product from the monopolist at the price of $\mathrm{P}$ and the second one is to buy only product B from firm 2. For the first option to be chosen by the consumers, $P$ should satisfy the following condition:

$$
\mathrm{v}_{\mathrm{A}}+\mathrm{v}_{\mathrm{B}}-\mathrm{P} \geq \mathrm{v}_{\mathrm{B}}-\mathrm{c}_{\mathrm{B} 2}
$$

This implies that the maximum price the tying firm can charge for the bundled product is given by $\mathrm{P}=\mathrm{v}_{\mathrm{A}}+\mathrm{c}_{\mathrm{B} 2}$. Firm 1's profit selling at that price is given by $\left(\mathrm{v}_{\mathrm{A}}+\mathrm{c}_{\mathrm{B} 2}\right)-\left(\mathrm{c}_{\mathrm{A}}+\right.$ $\left.\mathrm{c}_{\mathrm{B} 1}\right)=\left(\mathrm{v}_{\mathrm{A}}-\mathrm{c}_{\mathrm{A}}\right)+\left(\mathrm{c}_{\mathrm{B} 2}-\mathrm{c}_{\mathrm{B} 1}\right)$. Thus, firm 1's profit with bundling is given by

$$
\widetilde{\Pi}_{1}=\max \left[\left(\mathrm{v}_{\mathrm{A}}-\mathrm{c}_{\mathrm{A}}\right)+\left(\mathrm{c}_{\mathrm{B} 2}-\mathrm{c}_{\mathrm{B} 1}\right), 0\right]
$$

Thus, $\widetilde{\Pi}_{1}<\Pi_{1}$ unless firm 1 has cost advantages in market $B$, in which case it can be verified that bundling has no effect $\left(\widetilde{\Pi}_{1}=\Pi_{1}\right) .{ }^{11}$ This implies that firm 1 never has the incentive to bundle for the purpose of monopolizing the tied good market. As a result, price discrimination, as opposed to leverage, has come to be seen as the main motivation for tying (Stigler 1963, Adams and Yellen 1976, McAfee, McMillan, and Whinston 1986).

Note that given cost levels for each firm, non-bundling promotes static efficiency since it leads to production of B by the most efficient supplier. With bundling, however, production can come from the tying firm even though it has a higher cost of B as long as the cost disadvantage $\left(c_{B 1}-c_{B 2}\right)$ is less than the surplus available in market $A\left(s_{A}=v_{A}-c_{A}\right)$. In this simple model, the social and private incentives for (un)bundling coincide.

\footnotetext{
${ }^{11}$ Variables corresponding to bundling are denoted by a tilde.
} 


\section{The Revival of the Leverage Theory}

Recently, however, Whinston (1990) has revived the leverage theory of tying. He shows that if the market structure in the tied good market is oligopolistic and scale economies are present, tying can be an effective and profitable strategy to alter market structure by making continued operation unprofitable for tied good rivals. To understand Whinston's argument, I now modify the two stage game analyzed above such that firm 2 makes an entry decision after firm 1's bundling decision. The entry entails sunk fixed costs. More specifically, consider the following three-stage game.

In the first stage, firm 1 (the monopolistic supplier of product A) decides whether or not to bundle the two products. In the second stage, firm 2 makes its entry decision given firm 1's bundling decision. If it decides to enter the market, it pays a sunk cost of $K^{12}$ If there is entry by firm 2, a price game ensues in the final stage. The bundling decision is assumed to be irreversible. Thus, the model applies to physical or technical tying rather than contractual tying. ${ }^{13}$

I apply backward induction to solve the game. The outcomes in the final stage are the same as above if there is entry. If there is no entry, firm 1 charges $\left(v_{A}+v_{B}\right)$ if the products are bundled, and $\mathrm{v}_{\mathrm{A}}$ and $\mathrm{v}_{\mathrm{B}}$ for products $\mathrm{A}$ and $\mathrm{B}$, respectively, if the two products are not bundled. In either case, firm 1 gets the monopoly profits of $\left(\mathrm{v}_{\mathrm{A}}+\mathrm{v}_{\mathrm{B}}\right)-\left(\mathrm{c}_{\mathrm{A}}+\mathrm{c}_{\mathrm{B} 1}\right)$ without entry by firm 2 .

\footnotetext{
${ }^{12}$ If firm 2 is already in the market, it can avoid a fixed cost of operation $K$ by exiting from the industry.

${ }^{13}$ One example of technical tying through product design is Microsoft's integration of Internet Explorer (web browser program) and Media Player into its operating system. By designing these application programs to share the same files called dynamic linked libraries, it is difficult to remove them without jeopardizing the stability of the operating system.
} 
Now suppose that $K<\mathrm{c}_{\mathrm{B} 2}-\mathrm{c}_{\mathrm{B} 1}<\left(\mathrm{v}_{\mathrm{A}}-\mathrm{c}_{\mathrm{A}}\right)$. The first inequality means that firm 2 can successfully enter the market B if there was no bundling since its cost advantage is more than the sunk cost of entry. However, the second inequality implies that the cost advantage for firm 2 is not sufficiently high to compete against the bundled products since firm 1 is still able to sell the bundled products with a positive profit even if firm 2 priced its product at its marginal cost $c_{\mathrm{B} 2}$, i.e., $\widetilde{\Pi}_{1}=\left(\mathrm{v}_{\mathrm{A}}-\mathrm{c}_{\mathrm{A}}\right)+\left(\mathrm{c}_{\mathrm{B} 2}-\mathrm{c}_{\mathrm{B} 1}\right)>0$. Thus, firm 2 is foreclosed from market $B$ since it cannot recoup its sunk cost of entry when firm 1 engages in bundling.

Let $\mathrm{s}_{\mathrm{A}}=\mathrm{v}_{\mathrm{A}}-\mathrm{c}_{\mathrm{A}}(>0)$ denote the monopoly surplus in market A. One way to interpret the result above is that after bundling firm 1 behaves as if its cost of B were $\mathrm{c}_{\mathrm{B} 1}-$ $\mathrm{s}_{\mathrm{A}}$. The reason is that after bundling firm 1 can realize the monopoly surplus of $\mathrm{s}_{\mathrm{A}}$ only in conjunction with the sale of product B. Thus, the firm is willing to sell product B up to the loss of $\mathrm{s}_{\mathrm{A}}$. This implies that firm 1 will price more aggressively after bundling and capture a larger market share in market B. ${ }^{14}$ The Chicago school criticism of the leverage theory of tying missed this "strategic effect" due to their adherence to the assumption of competitive, constant returns-to-scale structure in the tied good market. It is important to keep in mind, however, that in Whinston's basic model, inducing the exit of the rival firm is essential for the profitability of tying arrangements. ${ }^{15}$ Thus, if the competitor has already paid the sunk cost of entry and there is no avoidable fixed cost, tying cannot be a profitable strategy. ${ }^{16}$

\footnotetext{
${ }^{14}$ In the terminology of Fudenberg and Tirole (1984), bundling is a "top dog" strategy, while non-bundling softens price competition and is a "puppy dog" strategy. (See Tirole 1988 for a discussion of the taxonomy of business strategies.)

${ }^{15}$ Whinston (1990) points out that if heterogeneity of consumer preferences is allowed for the tying good, tying can also serve as a price discriminating device and exclusion of the rival firm is not necessary for the profitability of tying. See also Carbajo et al. (1990).

16 In a related paper, Carbajo, De Meza and Seidmann (1990) also provide a strategic incentive for bundling. However, they are not concerned with the rival's entry or exit decisions. Instead, they show that bundling may
} 
The analysis of Whinston has been subsequently extended in several directions by various authors such as Carlton and Waldman (2002), Choi and Stefanadis (2001) and Nalebuff (2004). Whinston's model assumes that entry into the monopolized market is impossible and shows how tying can be used to extend monopoly power in one market into an otherwise competitive market. These papers, in contrast, consider an oligopolistic environment and show that bundling can be used to deter entry into a complementary market to preserve the monopolized market or strengthen market power across several markets.

The basic intuition for these results in Carlton and Waldman (2002) and in Choi and Stefanadis (2001) is that entry in one market is dependent on the success of entry in a complementary market. Carlton and Waldman develop a dynamic model where an entrant with a superior complementary product today can enter the primary product market in the future. They show that bundling can be used to deny an entrant sales when it has only the complementary product and this reduced sales today can prevent future entry into the primary market in the presence of scale economies. In Choi and Stefanadis (2001), entry takes place through innovation. They show that bundling reduces entrants' R\&D incentives and hence the probability of entry since success in both products is required to gain access to the market.

be profitable because it induces one's rival to price less aggressively. The reason is due to the assumption in their model that consumers are heterogeneous and can have different reservation values. However, for a given individual the reservation prices for the two goods are identical. In their model, tie-in provides a partitioning mechanism to sort consumers into groups with different reservation price characteristics. The firm with bundled products sells to high reservation value consumers while the competitor sells to low reservation value consumers. As a result, the rival firm can raise its price in equilibrium. The overall effect on the market is a relaxation of competition. See also Chen (1997). 
Nalebuff (2004) considers a situation in which an incumbent with two independent products faces one product entrant. He analyzes the strategy of bundling as an entry deterrence device when the incumbent does not know in which market the entry will take place. Nalebuff shows that bundling allows the incumbent to credibly defend both products without having to lower prices in each market.

\section{Tying and Innovation}

Whinston's paper mainly focuses on the effects of tying on pricing incentives. In Choi (1996, 2004), I extend Whinston's model by introducing R\&D incentives and uncover another channel through which tying can affect competition. As demonstrated by the recent Microsoft case, this extension is especially important in understanding tying incentives in innovative industries. ${ }^{17}$

To highlight the importance of R\&D, I abstract from the issue of entry/ exit by the rival firm and consider a model in which bundling is not profitable in the absence of R\&D competition. Instead, I show that the profitability of tying can be established through its effect on R\&D incentives. As shown in Section 2, with price competition only, using bundling to increase market share in the tied good market is not a profitable strategy in itself. However, bundling also affects R\&D competition. The tying firm's R\&D incentives in the tied good market increase since it can spread out the costs of $R \& D$ over a larger number of units, whereas the rival firms' $R \& D$ incentives decrease. If this positive effect

\footnotetext{
${ }^{17}$ See also Gilbert and Riordan (2003) who show that a monopoly supplier of an essential system component may have an incentive to engage in technological tying when firms invest to improve their products. In contrast to Choi (2004), they consider tying of two complementary products and assume that the wholesale price of the essential component controlled by the tying firm is fixed and cannot be used to extract rents from more efficient rivals of the complementary product.
} 
via $R \& D$ competition dominates the negative effect via price competition, tying can be beneficial for the tying firm even in the absence of exit by the rival firms

More specifically, I analyze a three-stage game identical to that in section 2, except that firms engage in $\mathrm{R} \& \mathrm{D}$ competition before the pricing game, thereby endogenizing the final production cost of each firm. That is, in the first stage, the monopolistic supplier of product A decides whether or not to bundle it with the competitively supplied product B. As in Whinston (1990) and Carbajo et al. (1990), I assume that this precommitment is made possible through costly investments in product design and the production process. In the second stage, the two firms engage in cost reducing R\&D activities. A price game ensues in the third and final stage, with the cost structure inherited from the realizations of R\&D. As usual, I solve the game via backward induction. The analysis of the pricing game stage is the same as in Section 2 above.

To focus on the impact of tying arrangements on $R \& D$ competition in the tied good market, I ignore the possibility of $R \& D$ in market $A$ and focus on the incentives for $R \& D$ in market B. ${ }^{18}$ Let $m_{1}$ and $m_{2}$ be the levels of cost-reducing $R \& D$ investments by firm 1 and firm 2, respectively. The R\&D outcomes are stochastic and independent across firms: let $\mathrm{x}_{1}$ and $x_{2}$ denote the cost realizations after R\&D for firm 1 and firm 2. Then, $x_{1}$ is a random variable drawn from $\left[0, \mathrm{c}_{1}\right]$ by a c.d.f. $\mathrm{F}\left(. \mathrm{m}_{1}\right)$ with positive density $\mathrm{f}\left(. \mid \mathrm{m}_{1}\right)$ for all $\mathrm{m}_{1}>0$. Similarly, $\mathrm{x}_{2}$ is a random variable drawn from a c.d.f. $\mathrm{G}\left(. \mid \mathrm{m}_{2}\right)$ with positive density $\mathrm{g}\left(. \mid \mathrm{m}_{2}\right)$ with all $\mathrm{m}_{2}>0$. Let $\mathrm{F}_{1}\left(. \mid \mathrm{m}_{1}\right)$ and $\mathrm{F}_{\mathrm{m}_{1} \mathrm{~m}_{1}}\left(. \mid \mathrm{m}_{1}\right)$ be the partial derivative and the second

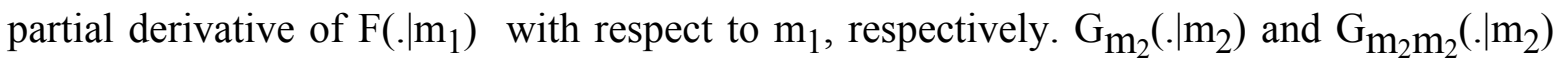
are defined analogously. I make the following assumptions.

\footnotetext{
${ }^{18}$ In Choi (1996), in contrast, the leverage of monopoly power occurs as a result of creating an interdependence of R\&D competition between the two product markets. Thus, the model in the present paper abstracts from this mechanism by assuming the R\&D possibility in only one market.
} 
Assumption 1. $\mathrm{F}_{\mathrm{m}_{1}}\left(. \mid \mathrm{m}_{1}\right)>0, \mathrm{G}_{\mathrm{m}_{2}}\left(. \mid \mathrm{m}_{2}\right)>0, \mathrm{~F}_{\mathrm{m}_{1} \mathrm{~m}_{1}}\left(. \mid \mathrm{m}_{1}\right)<0$, and $\mathrm{G}_{\mathrm{m}_{2} \mathrm{~m}_{2}}\left(. \mid \mathrm{m}_{2}\right)<0$ for all $\mathrm{m}_{1}, \mathrm{~m}_{2}, \mathrm{x}_{1} \in\left(0, \mathrm{c}_{1}\right)$ and $\mathrm{x}_{2} \in\left(0, \mathrm{c}_{2}\right)$.

Assumption 2. $\mathrm{F}_{\mathrm{m}_{1}}\left(\mathrm{x}_{1} \mid 0\right)=\infty, \mathrm{G}_{\mathrm{m}_{2}}\left(\mathrm{x}_{2} \mid 0\right)=\infty, \mathrm{F}_{\mathrm{m}_{1}}\left(\mathrm{x}_{1} \mid \infty\right)=0, \mathrm{G}_{\mathrm{m}_{2}}\left(\mathrm{x}_{2} \mid \infty\right)=0$, for all $\mathrm{x}_{1}$ $\in\left(0, \mathrm{c}_{1}\right)$ and $\mathrm{x}_{2} \in\left(0, \mathrm{c}_{2}\right)$.

Assumption 1 means that raising investment in $R \& D$ reduces cost in the sense of (reverse) first-order stochastic dominance, and does so at a diminishing rate. Assumption 2 is a boundary condition that guarantees an interior Nash equilibrium in R\&D investments.

\subsection{No Bundling}

In this case, consumers' purchase decisions for each product are independent of each other, which implies that each market can be analyzed separately.

Given firm 2's investment level $\mathrm{m}_{2}$, firm 1 chooses $\mathrm{m}_{1}$ to maximize the following expression:

$$
\begin{aligned}
& E\left[x_{2}-x_{1} \mid x_{1} \leq x_{2}\right]-m_{1}=\int_{0}^{c_{2}} \int_{0}^{x_{2}}\left(x_{2}-x_{1}\right) d F\left(x_{1} \mid m_{1}\right) d G\left(x_{2} \mid m_{2}\right)-m_{1} \\
& =\int_{0}^{c_{2}} \int_{0}^{x_{2}} F\left(x_{1} \mid m_{1}\right) d x_{1} d G\left(x_{2} \mid m_{2}\right)-m_{1}
\end{aligned}
$$

where the last line follows by integration by parts. The first order condition for the optimal investment level of firm 1 is given by:

$$
\int_{0}^{c_{2}} \int_{0}^{x_{2}} F_{m_{1}}\left(x_{1} \mid m_{1}\right) d x_{1} d G\left(x_{2} \mid m_{2}\right)=1
$$

Similarly, firm 2's optimal choice of $\mathrm{m}_{2}$ given $\mathrm{m}_{1}$ is derived as:

$$
\int_{0}^{c_{1}} \int_{0}^{x_{1}} G_{m_{2}}\left(x_{2} \mid m_{2}\right) d x_{2} d F\left(x_{1} \mid m_{1}\right)=1
$$

Equations (5) and (6) implicitly define firm 1's and 2's reaction functions, respectively, $\mathrm{m}_{\mathrm{i}}$ 
$=\mathrm{R}_{\mathrm{i}}\left(\mathrm{m}_{\mathrm{j}}\right)$, where $\mathrm{i}=1,2$ and $\mathrm{i} \neq \mathrm{j}$. Total differentiation of the first-order conditions yields the result that $\mathrm{R}_{\mathrm{i}}{ }^{\prime}<0$. Let $\mathrm{m}_{1}{ }^{*}$ and $\mathrm{m}_{2}{ }^{*}$ be the Nash equilibrium $\mathrm{R} \& \mathrm{D}$ investment levels under nonbundling. Then, $\left(\mathrm{m}_{1} *, \mathrm{~m}_{2} *\right)$ can be derived by finding the intersection of the two reaction functions. I further assume that $\left|R_{i}{ }^{\prime}\right|<1$. This ensures the uniqueness and the stability of the Nash equilibrium.

\subsection{Bundling}

Without bundling, firm 1 sells product $\mathrm{B}$ only in the event of $\mathrm{S}=$ $\left.\left\{\left(x_{1}, x_{2}\right) \in\left[0, c_{1}\right] \times\left[0, c_{2}\right] \mid x_{1} \leq x_{2}\right]\right\}$. In other words, any marginal cost reduction from investing in R\&D is useful only when the event $\mathrm{S}$ occurs. With bundling, firm 1 behaves as if its cost of product $\mathrm{B}$ were $\left(x_{1}-s_{A}\right)$, where $\mathrm{s}_{\mathrm{A}}=\mathrm{v}_{\mathrm{A}^{-}} \mathrm{c}_{\mathrm{A}}(>0)$. Thus, firm 1 sells the bundled product in the event of $\left.\widetilde{\mathrm{S}}=\left\{\left(x_{1}, x_{2}\right) \in\left[0, c_{1}\right] \times\left[0, c_{2}\right] \mid x_{1} \leq x_{2}+\mathrm{s}_{\mathrm{A}}\right]\right\}$, which is larger than set $\mathrm{S}$. In the event of set $\widetilde{\mathrm{S}}$, the tying firm's profit (gross of R\&D investment cost) is given by $\left(x_{2}+s_{A}-x_{1}\right)$. Thus, given firm 2's investment level $m_{2}$, the tying firm's optimization problem is to maximize the following expression:

$$
\begin{aligned}
& E\left[x_{2}+s_{A}-x_{1} \mid x_{1} \leq x_{2}+s_{A}\right]-m_{1}=\int_{0}^{c_{2}} \int_{0}^{x_{2}+s_{A}}\left(x_{2}+s_{A}-x_{1}\right) d F\left(x_{1} \mid m_{1}\right) d G\left(x_{2} \mid m_{2}\right)-m_{1} \\
& =\int_{0}^{c_{2}} \int_{0}^{x_{2}+s_{A}} F\left(x_{1} \mid m_{1}\right) d x_{1} d G\left(x_{2} \mid m_{2}\right)-m_{1}
\end{aligned}
$$

where the last line once again follows by integration by parts. The first order condition for the optimal investment level of firm 1 is given by:

$$
\begin{aligned}
& \int_{0}^{c_{2}} \int_{0}^{x_{2}+s_{4}} F_{m_{1}}\left(x_{1} \mid m_{1}\right) d x_{1} d G\left(x_{2} \mid m_{2}\right) \\
& =\int_{0}^{c_{2}} \int_{0}^{x_{2}} F_{m_{1}}\left(x_{1} \mid m_{1}\right) d x_{1} d G\left(x_{2} \mid m_{2}\right)+\int_{0}^{c_{2}} \int_{x_{2}}^{x_{2}+s_{4}} F_{m_{1}}\left(x_{1} \mid m_{1}\right) d x_{1} d G\left(x_{2} \mid m_{2}\right)=1(8)
\end{aligned}
$$

Equation (8) implicitly defines firm 1's reaction function under bundling, $\widetilde{m}_{1}=\widetilde{R}_{1}\left(m_{2}\right)$. 
The comparison of (5) and (8) immediately gives the result that for any given level of $m_{2}$, $\widetilde{m}_{1}=\widetilde{R}_{1}\left(m_{2}\right)>\mathrm{m}_{1}=\mathrm{R}_{1}\left(\mathrm{~m}_{2}\right)$ : firm 1 has greater incentives for $\mathrm{R} \& \mathrm{D}$ after bundling. The reason for this result is that the marginal cost reduction through $R \& D$ translates into profits conditional on the firm being able to sell product B. With tying arrangements, the set of outcomes under which firm 1 sells is larger, ( $\widetilde{\mathrm{S}}$ vs. $\mathrm{S}$ ), and as a result firm 1's R\&D incentives increase.

In contrast, firm 2's chances of selling product B decrease with firm 1's tying arrangements. Thus, firm 2's R\&D incentives are reduced as a result of bundling. To verify this, note that the first order condition for firm 2's optimal investment level is given by:

$$
\int_{0}^{c_{1}} \int_{0}^{x_{1}-s_{1}} G_{m_{2}}\left(x_{2} \mid m_{2}\right) d x_{2} d F\left(x_{1} \mid m_{1}\right)=1
$$

Equation (9) defines firm 2's reaction function under bundling, $\widetilde{m}_{2}=\widetilde{R}_{2}\left(m_{1}\right)$. The comparison of (6) and (9) gives the desired result, that is, for any given level of $m_{1}, \tilde{m}_{2}=$ $\widetilde{R}_{2}\left(m_{1}\right)<\mathrm{m}_{2}=\mathrm{R}_{2}\left(\mathrm{~m}_{1}\right)$. Let $\tilde{m}_{1} *$ and $\tilde{m}_{2} *$ denote the Nash equilibrium R\&D investment levels for the firm 1 (the tying firm) and firm 2 (the rival firm), respectively, under bundling. Then, $\left(\tilde{m}_{1}^{*}, \tilde{m}_{2}{ }^{*}\right)$ can be derived as the intersection of the two reaction functions $\widetilde{R}_{1}$ and $\widetilde{R}_{2}$

With bundling by firm 1, both firms' reaction curves shift. To analyze the effects of bundling on R\&D incentives, it is more convenient to consider the change in equilibrium as a result of sequential shifts of the two reaction curves (see Figure 1). Let $\left(\hat{m}_{1}^{*}, \hat{m}_{2}^{*}\right)$ be the intersection point of $\widetilde{R}_{1}\left(m_{2}\right)$ and $\mathrm{R}_{2}\left(\mathrm{~m}_{1}\right)$. Since $\widetilde{R}_{1}\left(m_{2}\right)$ is an outward shift of $\mathrm{R}_{1}\left(\mathrm{~m}_{2}\right)$, we have $\hat{m}_{1} *>\mathrm{m}_{1} *$ and $\hat{m}_{2} *<\mathrm{m}_{2} *$ with a stable Nash equilibrium. ${ }^{19} \widetilde{R}_{2}\left(m_{1}\right)$ is an inward shift of $\mathrm{R}_{2}\left(\mathrm{~m}_{1}\right)$, which implies that $\tilde{m}_{1} *>\hat{m}_{1} *$ and $\tilde{m}_{2} *<\hat{m}_{2} *$. Thus, we have $\widetilde{m}_{1} *>\mathrm{m}_{1} *$ and

\footnotetext{
${ }^{19}$ See Bulow et al. (1985) for the details of the proof.
} 
$\widetilde{m}_{2} *<\mathrm{m}_{2}{ }^{*}$. Thus, we can conclude that with bundling, the tying firm's R\&D investment level increases $\left(\widetilde{m}_{1} *>\mathrm{m}_{1}{ }^{*}\right)$, and the rival firm's R\&D investment level decreases $\left(\widetilde{m}_{2}{ }^{*}\right.$ $<\mathrm{m}_{2}{ }^{*}$ ). This result renders some credibility to the argument that tying by a dominant firm can stifle innovation incentives by competitors in the tied good market.

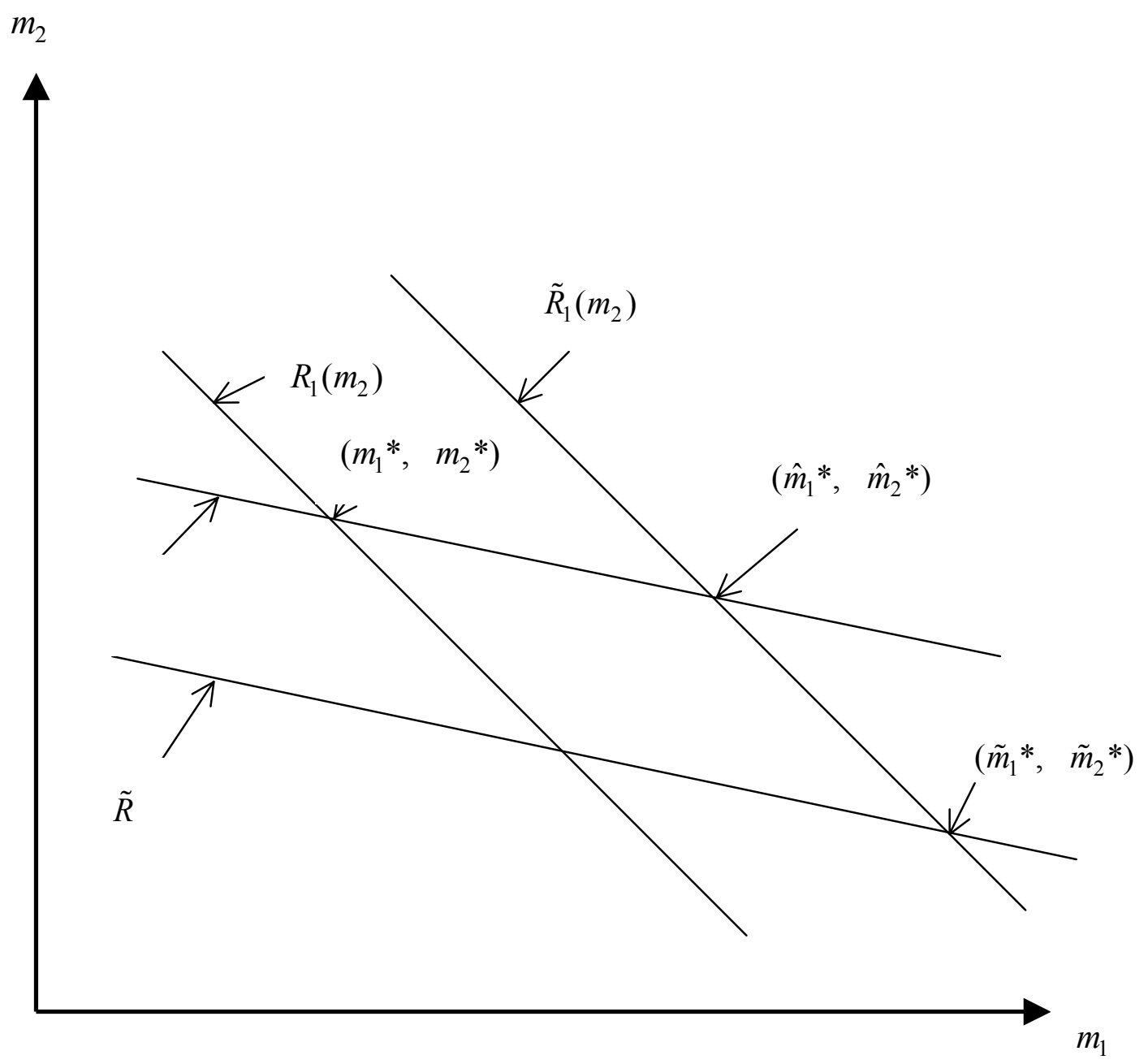

Figure 1. Equilibrium in R\&D Investment under Bundling and Nonbundling

In my model, market foreclosure does not necessarily lead to exclusion of the rival firm. Rather, market foreclosure in the product market translates into foreclosure in $R \& D$ markets. In the static model of price competition where the industry rent is fixed, bundling 
reduces the tying firm's overall profits since it intensifies the effective price competition in the tied good market. However, in the presence of dynamic rents that can be created through $R \& D$, bundling may be a profitable strategy. The change in $R \& D$ incentives through bundling enables the tying firm to capture a larger share of the dynamic rents. If this effect outweighs the negative effect of more aggressive price competition, bundling will be a privately optimal strategy even in the absence of exit by the rival firm.

An important question for antitrust policy is whether, in the presence of R\&D competition, bundling is socially beneficial. In this model, the answer to this question rests on the nature of R\&D competition, and there are two aspects of $R \& D$ to consider in evaluating its efficiency. R\&D competition can promote a diversity of research lines and thus increase the aggregate probability of success (the level of cost reduction) if the outcome of research project is uncertain. On the other hand, $R \& D$ competition can also result in the duplication of research efforts to the extent that their outcomes are correlated (Dasgupta and Maskin, 1987). The desirability of unfettered $R \& D$ competition hinges on the trade-off between diversity and duplication.

To explore welfare implications further, consider the following simple specification of the R\&D process. Each firm has the option of engaging in fixed intensity R\&D activities, the cost of which is given by $I$. The outcome of R\&D is modeled as a random draw for the firm's production cost. Let me further assume that the two firms are symmetric. They have the same initial cost, $\mathrm{c}\left(\mathrm{c}_{\mathrm{B} 1}=\mathrm{c}_{\mathrm{B} 2}=\mathrm{c}\right)$, and have access to the same technology. ${ }^{20}$ Specifically, if firm i invests in $R \& D$ at cost $I$, its production cost will be given by a realization of the random variable $\mathrm{x}_{\mathrm{i}}$, drawn from $[0, \mathrm{c}]$ with c.d.f. $\mathrm{F}($.$) and with positive$ density $f($.$) . With this specification of R \& D$, let me analyze each firm's incentive to engage

\footnotetext{
${ }^{20}$ See the Appendix for an analysis of the asymmetric case.
} 
in $R \& D$ activities depending on whether or not firm 1 bundles. Note that by assuming symmetry in the initial costs I abstract away from the issue of the static efficiency of bundling.

Define $\mu_{11}=E\left[x_{j}-x_{i} \mid x_{j}>x_{i}\right]$ and $\mu_{10}=E\left[c-x_{i}\right]$, where $x_{i}$ and $x_{j}$ denote the post $R \& D$ costs for firm $i$ and firm $j$, respectively, $j \neq i$. In other words, $\mu_{11}$ is the expected cost advantage of a firm when it has a lower post $R \& D$ cost compared to its rival firm, assuming that the rival firm is also engaged in $R \& D$. In contrast, $\mu_{10}$ denotes the expected cost saving from $R \& D$ and is the expected cost advantage of a firm when it is the only firm engaged in R\&D. Thus, $\mu_{10}>\mu_{11}>0$.

To simplify the analysis, I further assume that that $\mathrm{s}_{\mathrm{A}}=\mathrm{v}_{\mathrm{A}}-\mathrm{c}_{\mathrm{A}}$ is sufficiently large that $\mathrm{x}_{1}-\mathrm{s}_{\mathrm{A}}$ is always less than $\mathrm{x}_{2} \cdot{ }^{21}$ This implies that once the two products are bundled the tying firm always finds it optimal to sell the bundled product, regardless of the R\&D outcomes, and forecloses the rival firm. It should be emphasized that the simplifying assumption is made purely for expositional simplicity and is not crucial for the analysis. Even if I consider the possibility that the tying firm cannot sell the bundled product profitably (i.e., $\mathrm{x}_{1}-\mathrm{s}_{\mathrm{A}}>\mathrm{x}_{2}$ ) the main qualitative result will not change. The partial market foreclosure due to bundling reduces $R \& D$ incentives for the rival firm. However, with the assumption above, it is immediate that firm 2 has no incentive to invest in R\&D since it knows that it will be completely foreclosed from market B. Given this fact, the tying firm will invest in $R \& D$ if and only if $I$ is less than $\mu_{10}=E\left[c-x_{i}\right]$, which is the expected cost saving from $R \& D$.

\footnotetext{
${ }^{21}$ A sufficient condition for this to hold is that $\mathrm{s}_{\mathrm{A}}=\mathrm{v}_{\mathrm{A}}-\mathrm{c}_{\mathrm{A}}>\mathrm{c}_{\mathrm{B} 1}$. If this condition holds, the tying firm will still sell the bundled product even in the case where the rival firm reduces its production cost to zero and the tying firm maintains its initial production cost.
} 
In contrast, without bundling the equilibrium in $R \& D$ is characterized in the following way:

(i)If $I \in \boldsymbol{L}=\left[0, \mu_{11}\right]$, both firms invest in R\&D.

(ii)If $I \in M=\left(\mu_{11}, \mu_{10}\right)$, there are two (asymmetric) pure strategy equilibria in which either only firm 1 or only firm 2 invests in R\&D and there is one (symmetric) mixed strategy equilibrium in which both firms invest with probability $\frac{\mu_{10}-I}{\mu_{10}-\mu_{11}}$.

(iii)If $I \in \boldsymbol{H}=\left[\mu_{10}, \infty\right)$, neither firm invests in R\&D.

Finally, the socially optimal configuration of R\&D investment is given by:

(i)If $I \in \boldsymbol{L}=\left[0, \mu_{11}\right]$, both firms should invest in R\&D.

(ii)If $I \in \boldsymbol{M}=\left[\mu_{11}, \mu_{10}\right]$, only one firm should invest in R\&D.

(iii)If $I \in \boldsymbol{H}=\left[\mu_{10}, \infty\right)$, neither firm should invest in R\&D.

Combining all the results above, the effects of tying on welfare can be summarized in the following way (see Figure 2). If $I \in \boldsymbol{L}$, the benefit of $\mathrm{R} \& \mathrm{D}$ diversification outweighs the cost of duplication. Thus, it is better to have both firms engage in R\&D. In this case, nonbundling results in both firms investing in $R \& D$, and the private and social incentives coincide. Bundling, however, eliminates firm 2's incentives to invest in R\&D by foreclosing the market for firm 2. As a result, there is dynamic inefficiency associated bundling.

If $I \in M$, in contrast, the benefit of R\&D diversification is outweighed by the cost of duplication. Thus, it is better to have only one firm engage in R\&D. Bundling ensures that the private and social incentives coincide. Without bundling, whether private incentives 
result in socially optimal outcomes depends upon which of the multiple equilibria are selected. If one of the two asymmetric pure strategy equilibria is chosen, the private incentives again coincide with the socially optimal incentives. However, if the symmetric mixed strategy equilibrium is played, bundling improves dynamic efficiency. The reason is that with the symmetric mixed strategy equilibrium, the dynamic rents associated with R\&D are completely dissipated with competition. Thus, in this case, bundling can serve as a welfare improving coordination mechanism.

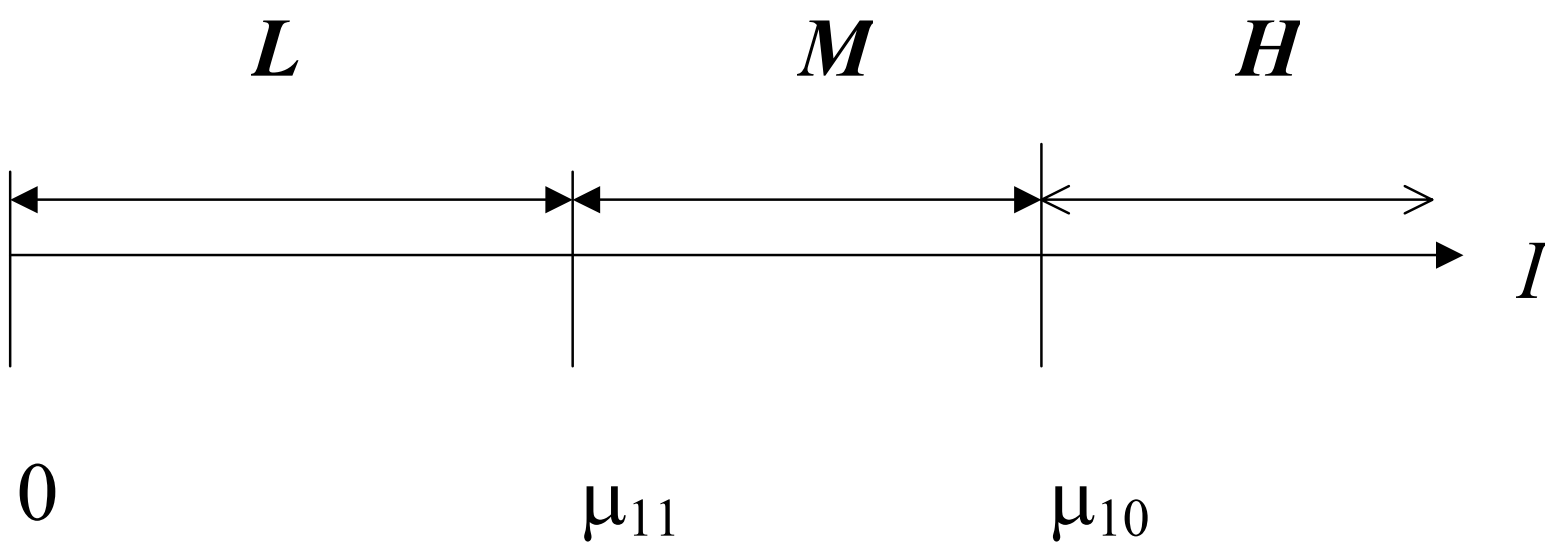

$\underline{\text { R\&D Equilibrium }}$ $\underline{\text { Without Bundling }}$

Both Firms Invest in R\&D

Symmetric Mixed Strategy Equilibrium

No Firm Invests

$\underline{\mathrm{R} \& \mathrm{D} \text { Equilibrium }}$ With Bundling

Only One Firm (the Tying Firm) Invests

Only One Firm (the Tying Firm) Invests

No Firm Invests

Socially Optimal

Both Firms Invest in R\&D

Outcome
Only One Firm Invests

No Firm Invests

Figure 2. Market Equilibrium vs. Socially Optimal Outcome 


\section{Merger with Bundling in Complementary Markets}

The possibility of bundling also has played an important role in merger analysis in complementary markets since a merger between producers of complementary goods enables the merging firms to offer the products sold independently prior to the merger as a bundle. This possibility became a stumbling block for the proposed merger between GE and Honeywell in the aerospace industry. Choi (2003) provides a framework to analyze the effects of mergers in complementary markets when the merged firm can engage in bundling. 22

Consider two complementary components, A and B, which consumers combine in fixed proportions on a one-to-one basis to form a final product. For instance, A and B can be considered as operating systems and application software, respectively, to form a computer system. In the case of the proposed GE/Honeywell merger, they correspond to engines and avionics to form an aircraft.

I assume that there are two differentiated brands of each of the two components A $\left(A_{1}\right.$ and $\left.A_{2}\right)$ and $B\left(B_{1}\right.$ and $\left.B_{2}\right)$. There are four ways to form a composite product, $A_{1} B_{1}$, $A_{1} B_{2}, A_{2} B_{1}$, and $A_{2} B_{2}$. Let me denote the price of brand $A_{i}$ by $p_{i}$ and the price of brand $B_{j}$ by $q_{j}$, where $\mathrm{i}=1,2$ and $\mathrm{j}=1,2$. Then the composite product $\mathrm{A}_{\mathrm{i}} \mathrm{B}_{\mathrm{j}}$ is available at the total system price of $s_{i j}=p_{i}+q_{j}$ (see Figure 3$)$.

\footnotetext{
${ }^{22}$ Choi's (2003) framework is an extension of Economides and Salop (1992) who analyze a model of competition with complementary products in which they derive equilibrium prices for a variety of organizational and market structures that differ in their degree of competition and integration. However, they limit the strategy space of the merged entity and do not consider the possibility of bundling. See also Choi (2001) for a discussion of the GE/Honeywell merger.
} 
Figure 3: Diagrammatic representation of the pre-merger situation
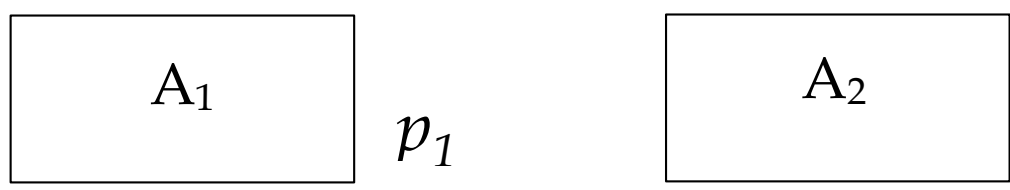

$p_{2}$
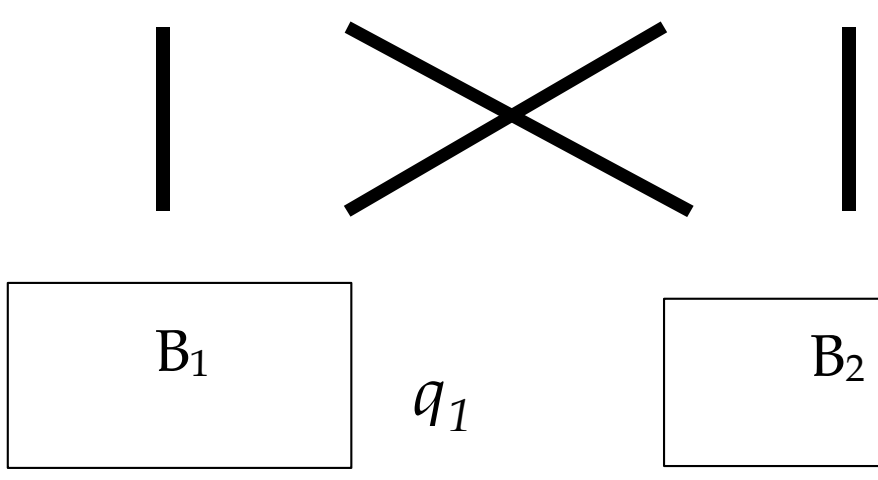

$q_{1}$

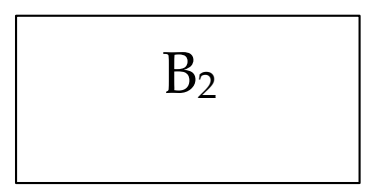

$q_{2}$

Let $D^{i j}$ denote demand for the composite product $\mathrm{A}_{\mathrm{i}} \mathrm{B}_{\mathrm{j}}$. The demand function for the components then can be derived from the demand functions for the composite goods. For instance, component $A_{i}$ is sold as a part of composite goods $A_{i} B_{1}$ and $A_{i} B_{2}$. Thus, the demand for component $\mathrm{A}_{\mathrm{i}}$ is given by

$$
D^{A i}=D^{i 1}+D^{i 2}
$$

Similarly, the demand for component $\mathrm{B}_{\mathrm{j}}$ is given by

$$
\mathrm{D}^{B j}=\mathrm{D}^{l j}+\mathrm{D}^{2 j}
$$

For simplicity, I assume the following linear and symmetric demand system:

$$
\begin{aligned}
& D^{11}\left(s_{11}, s_{12}, s_{21}, s_{22}\right)=a-b s_{11}+c s_{12}+d s_{21}+e s_{22} \\
& D^{12}\left(s_{12}, s_{11}, s_{22}, s_{21}\right)=a-b s_{12}+c s_{11}+d s_{22}+e s_{21} \\
& D^{21}\left(s_{21}, s_{22}, s_{11}, s_{12}\right)=a-b s_{21}+c s_{22}+d s_{11}+e s_{12} \\
& D^{22}\left(s_{22}, s_{21}, s_{12}, s_{11}\right)=a-b s_{22}+c s_{21}+d s_{12}+e s_{11}, \text { where } a, b, c, d, e>0 .
\end{aligned}
$$


To ensure that composite goods are gross substitutes, it is assumed that $b>c+d+e$, where the " $a$ " parameter represents the market size, the " $b$ " parameter represents the own-price elasticity of demand for that system, and the " $c, d, e$ " parameters represent the cross-price elasticity of demand across systems. Without loss of generality, I assume that constant unit production costs are zero. ${ }^{23}$

In such a framework, Choi (2003) analyzes how the market equilibrium changes after a merger between A1 and B1 when the merged firms engage in mixed bundling. The main results are summarized as follows:

1. The merged firm will reduce the price of its bundled system and expand market share relative to the situation prior to the merger. Prior to the merger, any price cut by one of the merging firms will tend to benefit the other's sales. In the absence of the merger, neither party will take account of this benefit of a price cut on the other's sales. Following the merger, however, the merged entity can "internalize" these "pricing externalities" arising from the complementarity of their components by reducing the price of the bundle to below the level the two players would choose if acting independently. ${ }^{24}$ This will expand the merged firm's sales and market share.

2. The merged firm will raise the prices of its stand-alone components, relative to their levels prior to the merger. The merged firm has less to lose from raising its stand-alone prices because a proportion of those customers that switch away from the stand-alone components as a result of the price increase will simply switch to the bundle offered by the

\footnotetext{
${ }^{23}$ If there are positive constant unit production costs, the prices in the model can be interpreted as per unit margins.

${ }^{24}$ Cournot (1838) was the first to note that mergers among complements reduce prices. He considered the merger of two monopolists that produce complementary goods (zinc and copper) that are used as inputs for a final good (brass). My model extends his analysis to a case where both input producers face oligopolistic competition.
} 
merged firm rather than to the competing system from independent firms. As such, the merged party will have an increased incentive to set high prices for its components. This raises the price of "mix-and-match" systems (i.e. systems including a component of the merged firm alongside a competitor's component) and makes them less attractive to buyers.

3. In response to the price cut by the merged firm for their bundled system and the price increase for the 'mix-and-match' systems, the independent rivals will cut price in order to retain some market share. However, they will not cut their prices as much as the merged firm (i.e. their system will remain more expensive than the bundled system of the merged firm) since - in the absence of counter-merger - they cannot internalize the externality arising from the complementarity of their components. As a result, they will fail to recapture all of their prior market shares. The merger would therefore reduce the profits of the merged firm's competitors. This reduction in profits follows directly from the combination of a loss of market share and the need to cut prices. Thus, there is a distinct possibility of exit by outside rival firms.

As an example, consider the case where $a=b=1$ and $c=d=e=1 / 4$ (see Figure 4). Then it can be shown that with the independent ownership (pre-merger) structure, $p_{1}^{I}=p_{2}^{I}=q_{1}^{I}=q_{2}^{I}=4 / 5$. The total price of each composite good is $8 / 5$ and each firm gets profits of $24 / 25$. After the merger between $A_{1}$ and $B_{1}$, the merged entity $\left(A_{1}-B_{1}\right)$ charges $\tilde{s}=11 / 8$ for the bundle and $\tilde{p}_{1}=\widetilde{q}_{1}=1$ for separate components. Thus, it offers discount for the bundle $(11 / 8<1+1=2)$. Independent producers, $\mathrm{A}_{2}$ and $\mathrm{B}_{2}$, charge $\widetilde{p}_{2}=\widetilde{q}_{2}=3 / 4$ for their component products. Thus, the prices for composite products, $A_{1} B_{1}, A_{1} B_{2}, A_{2} B_{1}$, and $\mathrm{A}_{2} \mathrm{~B}_{2}$ are given by $11 / 8,7 / 4,7 / 4$, and $3 / 2$, respectively, where $7 / 4>3 / 2>11 / 8$. After the merger $A_{1}-B_{1}$ receives the profits of $129 / 64(>24 / 25+24 / 25)$, whereas independent producers get 27/32 $(<24 / 25)$. This implies that $A_{1}$ and $B_{1}$ together increase their combined profits after merger while independent producers' profits decrease. 
Figure 4: Diagrammatic representation of post -merger per unit margins

(with $a=b=1, c=d=e=1 / 4$ )
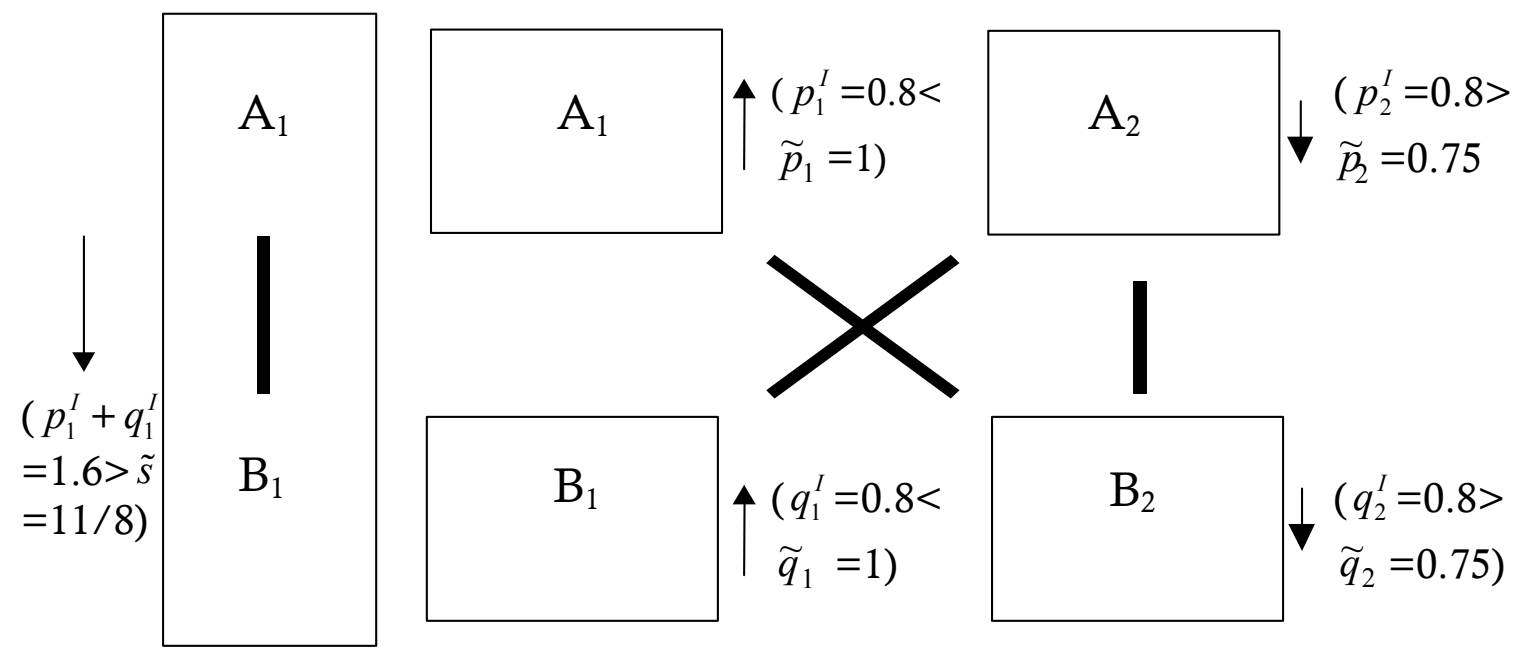

The analysis suggests that a merger with bundling in complementary markets may have both anticompetitive effects and efficiency benefits. The efficiency benefits, for instance, take the form of internalizing pricing extenalities for the merged firm. The potential anticompetitive effects would take the form of market foreclosure, over either the short or the medium term. If the financial impact of the merged firm's bundling made its rivals unable to cover their fixed costs of production, their short-term exit could be expected. Alternatively, even if their post-merger profitability enabled them to remain in the market over the short term, it might not justify new R\&D investment or capital expenditure. This would have serious consequences for their viability over the medium term. 
Even in the absence of such foreclosure effects, mixed bundling by the merging parties could adversely affect consumer and social welfare. With heterogeneous consumer preferences, some buyers gain and others lose. For instance, those who previously purchased both products from the two merging firms would gain due to the lower bundle price. However, those who purchased a "mix and match" system and wished to continue doing so would suffer due to the increased stand-alone prices charged by the merged firm. In Choi (2003), I conduct a welfare analysis by numerical simulation under the assumption that $c=d=e<1 / 3$. I find that there could be significant welfare loss when $c$ (crosssubstitutability parameter) is sufficiently large. When $c$ is close to zero, each system is essentially a separate product, and there is little direct competition between systems. In this case, the structure of each system market is equivalent to the one considered by Cournot and mergers are welfare enhancing. In cases with high degrees of substitutability and intense competition among systems (i.e., high $c$ ), however, the model suggests that the effects of mergers on social welfare are negative.

In Choi (2003), I also analyze the effects of a merger with pure bundling under which the firm only sells the bundle and does not make the individual components available individually. While the analysis of mixed bundling is more appropriate in the short-run, the possibility of pure bundling can be important for the long run analysis since the merged firm can practice pure bundling in the form of technical tying when it develops new generations of products by making its products available only as an integrated system, incompatible with the individual components offered by outside suppliers. With a simulation analysis, I show that for most parameter values pure bundling is less profitable than mixed bundling for the merged entity. It is also shown that outsiders' profits are affected more adversely with pure bundling. I can conclude that the merged firm will not practice pure bundling since mixed bundling yields higher profits as an accommodation strategy. However, as in Whinston 
(1990), pure bundling can be still profitable if the exclusion of rivals through predation is possible with pure bundling, but not with mixed bundling.

\section{Tying in Two-Sided Markets}

Motivated by the recent tying cases involving credit card payment systems and Microsoft, a few studies analyze the effects of tying arrangements on platform competition in so-called two-sided markets. A favorite example to illustrate the defining characteristics of two-sided markets is dating services or nightclubs where each member of two distinct groups of people (men and women) derives value from interacting with members of the other group. In this example, members of each group obviously derive higher utility as more people from the other group patronize the same dating service or nightclub. This type of inter-group network externality is not limited to dating services. Other examples with more significant economic importance include auction sites such as eBay and Yahoo where buyers and sellers get together to consummate a deal, credit card payment systems such as Visa and MasterCard where both merchants and consumers need to participate in the same system, video game platforms such as PlayStation, X-box and GameCube where game developers and consumers constitute the two distinct sides, etc. ${ }^{25}$ In such markets, the need to get all sides of the market to get on board creates a so-called "chicken and egg" problem (Caillaud and Jullien, 2003) in that members of each group are willing to participate in the market only if they expect many members from the other side to participate. The burgeoning literature on two-sided markets is mainly concerned with the optimal pricing structure to coordinate the demands of distinct groups of customers. Formal economic

\footnotetext{
${ }^{25}$ See Evans (2003) and Rochet and Tirole (2003a) for more examples of multi-sided markets.
} 
analysis of tying that explicitly accounts for the peculiarities of two-sided markets, however, is scarce. ${ }^{26}$ Two exceptions are Rochet and Tirole (2003) and Choi (2004).

More specifically, Rochet and Tirole (2003b) provide an economic analysis of the tying practice initiated by payments card associations Visa and MasterCard in which merchants who accept their credit cards were forced also to accept their debit cards. This tie-in practice, the so-called "honor-all-cards" rule, has been challenged recently by major merchants including Walmart in a class action suit. In the class action suit on behalf of thousands of retailers, the stores argued that Visa and MasterCard unfairly required merchants to accept their debit cards, which require a customer's signature to verify a transaction, to exclude PIN-based on-line debit cards. They show that in the absence of tying, the interchange fee between the merchant's and the cardholder's banks on debit is too low and tends to be too high on credit compared to the social optimum. Tying is shown to be a mechanism to rebalance the interchange fee structure and raise social welfare.

In Choi (2004), I develop a preliminary model that reflects the Microsoft case in the EC where it has been alleged that the company's tying practice of requiring Windows operating system users to accept its Windows Media Player software is predatory and hurts digital media rivals such as RealNetworks. ${ }^{27}$ In this streaming media software case, content providers and consumers constitute the two sides of the market. ${ }^{28}$

\footnotetext{
${ }^{26}$ The general economics of multi-sided markets are provided in Armstrong (2002), Rochet and Tirole (2003a), and Caillaud and Jullien (2003)

${ }^{27}$ On March 24, 2004, the European Union ruled that Microsoft is guilty of abusing the "near-monopoly" of its Windows PC operating system and fined it a record 497 million euros ( $\$ 613$ million). The case is being appealed by Microsoft. On December 18, 2003, streaming-media provider RealNetworks also sued Microsoft on antitrust charges in the US court, claiming that Microsoft wielded its "monopoly power to restrict how PC makers install competing media players while forcing every Windows user to take Microsoft's media player, whether they want it or not." See New York Times, December 19, 2003, for more details.

${ }^{28}$ The case is certainly reminiscent of the earlier DOJ anti-trust suit against Microsoft involving the tie-in of Internet Explorer web browser with the Windows operating system. Despite the obvious parallels between the
} 
In my model, there are two intermediaries competing for market share within each group. $^{29}$ There is free entry in the market for content provision. Content providers are heterogeneous in their fixed cost of creating content which need to be incurred twice if they multi-home, i.e., make their contents available in digital form on both platforms. The choice of consumers' platform is analyzed by adopting the Hotelling model of product differentiation in which the two platforms are located at the two extreme points of a line. Consumers are uniformly distributed along the line and each consumer's utility of participating in a platform depends on the number of content providers on the same platform.

In this model I compare the market outcomes under tying and no tying and provide a welfare analysis. There are three channels through which tying can affect social welfare due to the monopolization of both sides of the market. First, all consumers patronize the tying firm's platform. This implies that there is less variety in the market. As a result, there are less desirable matches between the consumers and platforms, leading to higher overall "transportation costs." Second, content is provided only on the tying firm's platform, whereas the same content was produced on both platforms in the absence of tying. Thus, there are savings in duplication costs under tying. Third, the number of entrants in the content side of the market that determines the availability of content can differ across regimes. The first effect is negative while the second effect is positive. The sign of the

\footnotetext{
two cases, there seems to be a major difference between the earlier case involving the tie-in of web browsers and the current case of tie-ins of the media player with respect to compatibility between software of competitors. More specifically, any web pages can be accessed either by Internet Explorer or Netscape browsers. Thus, from the perspective of content providers, it does not matter which program viewers use to access their sites, and the two-sidedness of the market is lacking. In the media player software case, however, competing platforms are incompatible. Any media content created and encoded by RealNetworks software such as RealProducder can be played only by RealPlayer and the same applies for the Microsoft's Media Player platform.

${ }^{29}$ The model is a modification of the framework developed by Armstrong (2002) and Rochet and Tirole (2003a).
} 
third effect is ambiguous. The coordination of consumers on the tying firm's platform enhances the incentive to enter the content side of the market. However, the tying firm's pricing decision in that side of the market can offset this positive effect. The preliminary result thus suggests that the welfare implications of tying depend on the relative magnitude of inter-group externalities and the extent of product differentiation. If the extent of intergroup externalities is significant compared to that of product differentiation, tying can be welfare-enhancing since the benefit from internalizing the inter-group network externalities outweighs the loss of product variety. Otherwise, tying reduces welfare.

Tying can be a very effective mechanism through which a dominant firm in a related market can penetrate one side of the two-sided market to gain an advantage in competition for the other side. As such, we are expected to observe more tying cases in two-sided markets, and it is essential to understand the impacts of tying on competition in such markets and their welfare consequences. Both Rochet and Tirole (2003) and Choi (2004), however, are tailored to analyze specific cases of the payment card and media software industries, respectively. It would be desirable to develop a unified and more general framework that can encompass a variety of two-sided market situations.

\section{Concluding Remarks on Policy Implications}

I have conducted a selective review of recent developments in the theory of tying. Traditionally, tying arrangements have received a harsh treatment in the US courts and had a status very close to per se violation for a long time with the leverage theory being the key intellectual rationale behind such treatment. The criticisms originating from the Chicago school, however, exposed the logical flaws of the theory and instead stressed the efficiency rationale for tying, which led to a more benign view of such arrangements. The subsequent literature has refined the classical leverage theory by identifying conditions under which 
tying can be used to preserve monopoly power or extend monopoly power in one market to another, showing that the Chicago school argument can break down in a variety of settings.

The welfare implications of tying arrangements are in general ambiguous because tying could have efficiency effects even when it has harmful exclusionary effects. Microsoft's tying of Internet Explorer and Media Player with its operating system is a case in point. The literature suggests that such technical tying can be exclusionary. At the same time, however, there may be offsetting effects of tying such as enhanced performance due to a seamless integration of products and reduced costs of distribution if the tying good and the tied good are often used.

As such, there seems to be a consensus emerging among economists that tying should not be treated as per se violation of antitrust laws and that the rule of reason should be adopted in the assessment of tying arrangements. ${ }^{30}$ However, beyond the general principle that any sensible antitrust policy should balance possible efficiency effects against potential anti-competitive effects, it seems to be an elusive goal to come up with a simple legal standard to apply in antitrust cases since the appropriate antitrust policy will depend on the specifics of the case.

${ }^{30}$ See Motta (2004) and Tirole (2004). 


\section{References}

Adams, William, J. and Yellen, Janet L., "Commodity Bundling and the Burden of Monopoly”, Quarterly Journal of Economics, 90, August 1976, p. 475-498.

Armstrong, Mark, "Competition in Two-Sided Markets," unpublished manuscript, August 2002.

Bork, Robert H. (1978). The Antitrust Paradox: A Policy at War with Itself. New York, New York: Basic Books.

Bowman, Ward, "Tying Arrangements and the Leverage Problem," Yale Law Journal, 1957, 67, pp.19-36.

Bulow, Jeremy I., Geanakoplos, John D. and Klemperer, Paul D., "Multimarket Oligopoly: Strategic Substitutes and Complements," Journal of Political Economy, June 1985, 93, 488511.

Caillaud, Bernard and Jullien, Bruno, "Chicken and Egg: Competition among Intermediation Service Providers," Rand Journal of Economics, Summer 2003, pp. 309-328.

Carbajo, Jose, De Meza, David and Seidman, Daniel J., "A Strategic Motivation for Commodity Bundling," Journal of Industrial Economics, March 1990, 38, pp. 283-298.

Carlton, Dennis, W. and Waldman, Michael, "The Strategic Use of Tying to Preserve and Create Market Power in Evolving Industries," Rand Journal of Economics, Summer 2002, pp. 194-220.

Chen, Yongmin, "Equilibrium product bundling," Journal of Business, 70, 1997, pp. 85-103.

Choi, Jay Pil, "Preemptive R\&D, Rent Dissipation, and the Leverage Theory," Quarterly Journal of Economics, 1996, pp. 1153-1181.

Choi, Jay Pil, "A Theory of Mixed Bundling Applied to the GE-Honeywell Merger," Antitrust, Fall 2001, pp. 32-33.

Choi, Jay Pil, "Tying and Innovation: A Dynamic Analysis of Tying Arrangements," Economic Journal, Economic Journal, 2004.

Choi, Jay Pil, "Merger with Bundling in Complementary Markets," unpublished manuscript, 2003.

Choi, Jay Pil, “Tying in Multi-Sided Markets,” unpublished manuscript, 2004. 
Choi, Jay Pil and Stefanadis, Chris, "Tying, Investment, and the Dynamic Leverage Theory", Rand Journal of Economics, 2001, pp. 52-71.

Cournot, Augustine, "Researches into the Mathematical Principles of the Theory of Wealth", originally published in French (1838), translated by Nathaniel Bacon, New York: Macmillan, 1927.

Dasgupta, Partha and Maskin, Eric, "The Simple Economics of Research Portfolios," Economic Journal, 1987, 97, pp. 587-595.

Economides, Nicholas and Salop, Steven C., "Competition and Integration among Complements, and Network Market Structure," Journal of Industrial Economics, XL, 1992, pp. $105-123$.

Evans, David S., "The Antitrust Economics of Multi-Sided Platform Markets," Yale Journal on Regulation, Summer 2003, 20, pp. 325-381.

Farrell, Joseph, Monroe, Hunter and Saloner, Garth, "The Vertical Organization of Industry: Systems Competition versus Component Competition," Journal of Economics and Management Strategy, Summer 1998, 7, pp. 143-182.

Farrell, Joseph and Saloner, Garth, "Installed Base and Compatibility: Innovation, Product Preannnouncements, and Predation," American Economic Review (76), December 1986, pp. 940-955.

Fudenberg, Drew, and Tirole, Jean,"The Fat Cat Effect, the Puppy Dog Ploy and the Lean and Hungry Look," American Economic Review, Papers and Proceedings, 1984, 74, 361368.

Gilbert, Robert J. and Riordan, Michael H., "Product Improvement and Technological Tying in a Winner-Take-All Market," unpublished manuscript, 2003.

Lewbel, Arthur, "Bundling of Substitutes or Complements," International Journal of Industrial Organization, 1985, 3, 101-107.

Matutes, Carmen and Regibeau, Pierre, "Mix and Match: Product Compatibility Without Network Externalities," Rand Journal of Economics, 1988, pp. 221-234.

McAfee, Preston R., McMillan, John and Whinston, Michael D., "Multiproduct Monopoly, Commodity Bundling, and Correlation of Values", Quarterly Journal of Economics, 104, May 1989, pp. 371-384.

Motta, Massimo, Competition Policy: Theory and Practice, Cambridge University Press, 2004.

Nalebuff, Barry, "Bundling, Tying and Portfolio Effects, Parts 1 and 2," Department of Trade and Industry Economics Paper No. 1, 2003. 
Nalebuff, Barry, "Bundling as an Entry Barrier," Quarterly Journal of Economics, 119, February 2004, pp. 159-188.

Posner, Richard A., Antitrust Law: An Economic Perspective, Chicago: University of Chicago Press, 1976.

Rochet, Jean-Charles and Tirole, Jean, "Platform Competition in Two-Sided Markets," Journal of the European Economic Association, June 2003a, 1, pp. 990-1029.

Rochet, Jean-Charles and Tirole, Jean, "Tying in Two-Sided Markets and the Impact of the Honor All Cards Rule," unpublished manuscript, September 2003b.

Schmalensee, Richard, "Gaussian Demand and Commodity Bundling," Journal of Business, 1984, 57, S211-S230.

Stigler, George J., "United States v. Loew's Inc.: A Note on Block Booking," Supreme Court Review, 1963, 152, 152-157.

Tirole, Jean, The Theory of Industrial Organization, Cambridge, Massachusetts: The MIT Press.

Tirole, Jean, “The Analysis of Tying Cases: A Primer,” July 2004, unpublished manuscript.

Whinston, Michael D., "Tying, Foreclosure, and Exclusion," American Economic Review, Vol. 80, No. 4, 1990, pp. 837-859.

Whinston, Michael D., "Exculsivity and Tying in U.S. v. Microsoft: What We Know, and Don’t Know," Journal of Economic Perspectives, 2001, pp. 63-80. 


\section{Appendix: The Analysis of Asymmetric Cost Structures in Section 4}

In the Appendix, I analyze the case where the two firms are asymmetric in their initial costs. Otherwise, I retain all the assumptions in Section 4. Furthermore, I assume that the realization of $R \& D$ outcome is uniformly distributed; if a firm with a current unit cost of $\mathrm{c}$ performs $\mathrm{R} \& \mathrm{D}$, the outcome of which will be a random variable $\widetilde{c}$ distributed uniformly over $[0, \mathrm{c}]$. When the two firms differ in their initial costs, this specification captures the following features of $R \& D$ process:

Diminishing Returns to R\&D. When a firm with a current unit cost of $\mathrm{c}$ invests in $\mathrm{R} \& \mathrm{D}$, the expected cost saving is given by $\mathrm{c} / 2$. As the original cost level $\mathrm{c}$ approaches to the limit zero, the expected cost saving or improvement from R\&D decreases.

Experience Effects. However, the final expected cost (Post R\&D cost) will be smaller for a firm with a lower initial production cost (Pre R\&D cost).

The analysis in this Appendix runs parallel to the one in Section 4, which can be considered as a special case of the analysis in the Appendix.

\section{A.1. No Bundling}

To analyze how the incentives for $\mathrm{R} \& \mathrm{D}$ depends on the initial cost structure, suppose that the initial costs of the two firms are given by $c_{\mathrm{L}}$ and $\mathrm{c}_{\mathrm{H}}$, where $\mathrm{c}_{\mathrm{L}}<\mathrm{c}_{\mathrm{H}}$. The firm with the initial cost of $c_{L}\left(c_{H}\right)$ is called the low (high) cost firm. Let me denote the R\&D decision of firm i by $\mathrm{I}_{\mathrm{i}} \in\{0, I\}, \mathrm{i}=\mathrm{L}, \mathrm{H}$. Let $\pi_{\mathrm{i}}\left(\mathrm{I}_{\mathrm{i}}, \mathrm{I}_{\mathrm{j}}\right)$ be the expected profit for firm $\mathrm{i}$ when its investment level is given by $I_{i}$ and the other firm's investment level is given by $I_{j}$, where $\mathrm{i}, \mathrm{j}=\mathrm{L}, \mathrm{H}$, and $\mathrm{j} \neq \mathrm{i}$. Then,

$$
\pi_{\mathrm{H}}(\boldsymbol{I}, \boldsymbol{I})=\mathrm{E}[\mathrm{x}-\mathrm{y} \mid \mathrm{x}>\mathrm{y}]-I
$$


where $\mathrm{x}$ and $\mathrm{y}$ denote post $\mathrm{R} \& \mathrm{D}$ cost for the low cost firm and the high cost firm, respectively. By using the fact that $\mathrm{x}$ is uniformly distributed on $\left[0, \mathrm{c}_{\mathrm{L}}\right]$ and $\mathrm{y}$ is uniformly distributed on $\left[0, \mathrm{c}_{\mathrm{H}}\right]$,

$$
\begin{aligned}
\pi_{\mathrm{H}}(\boldsymbol{I}, \boldsymbol{I}) & =\mathrm{E}(\mathrm{x} \mid \mathrm{x}>\mathrm{y}]-\mathrm{E}[\mathrm{y} \mid \mathrm{x}>\mathrm{y}]-I \\
& =\int_{0}^{c_{L}} \frac{x}{c_{H}} \frac{x}{c_{L}} d x-\int_{0}^{c_{L}}\left(1-\frac{y}{c_{L}}\right) \frac{y}{c_{H}} d y-I \\
& =\frac{c_{L}^{2}}{6 c_{H}}-I=\frac{c_{L}}{6 \gamma}-I, \text { where } \gamma=\frac{c_{H}}{c_{L}} \geq 1 .
\end{aligned}
$$

By proceeding in a similar manner, I have

$$
\begin{aligned}
& \pi_{\mathrm{H}}(\boldsymbol{I}, 0)=\frac{c_{L}^{2}}{2 c_{H}}-I=\frac{c_{L}}{2 \gamma}-I \\
& \pi_{\mathrm{H}}(0,0)=\pi_{\mathrm{H}}(0, I)=0 \\
& \pi_{\mathrm{L}}(I, I)=\frac{3 c_{H}^{2}-3 c_{H} c_{L}+c_{L}^{2}}{6 c_{H}}-I=\frac{c_{L}}{6 \gamma}+\frac{(\gamma-1) c_{L}}{2}-I \\
& \pi_{\mathrm{L}}(I, 0)=c_{H}-\frac{c_{L}}{2}-I=\left(\gamma-\frac{1}{2}\right) c_{L}-I \\
& \pi_{\mathrm{L}}(0,0)=c_{H}-c_{L}=(\gamma-1) c_{L} \\
& \pi_{\mathrm{L}}(0, I)=\frac{\left(c_{H}-c_{L}\right)^{2}}{2 c_{H}}=\frac{(\gamma-1)^{2} c_{L}}{2 \gamma}
\end{aligned}
$$

Thus, I can draw the following payoff matrix as in Figure A-1. 


\section{The High Cost Firm (H)}

R\&D Investment

\begin{tabular}{|c|c|}
\hline$\frac{c_{L}}{6 \gamma}+\frac{(\gamma-1) c_{L^{\tau}}}{2} I, \frac{c_{L}}{6 \gamma} I$ & $\left(\gamma-\frac{1}{2}\right) \tilde{c_{L}} I, 0$ \\
\hline$\frac{(\gamma-1)^{2} c_{L}}{2 \gamma}, \frac{c_{L}}{2 \gamma} I$ & $(\gamma-1) c_{L}, 0$ \\
\hline
\end{tabular}

Figure A-1. The Payoff Matrix of the R\&D Game with Non-bundling

A straightforward calculation yields the following result.

Proposition A1. Without bundling, the equilibrium in $R \& D$ is characterized in the following way.

The large Efficiency Gap Case $\left(\gamma=\mathrm{c}_{\mathrm{H}} / \mathrm{c}_{\mathrm{L}}>5 / 3\right)$

In this case, the equilibrium is unique and is characterized in the following way.

(i)If $I \in \boldsymbol{L}=\left[0, \frac{c_{L}}{6 \gamma}\right]$, both firms invest in R\&D.

(ii)If $I \in M=\left[\frac{c_{L}}{6 \gamma}, \frac{c_{L}}{2}\right]$, only the low cost firm invest in R\&D.

(iii)If $I \in \boldsymbol{H}=\left[\frac{c_{L}}{6 \gamma}, \infty\right)$, neither firm invests in R\&D.

The Small Efficiency Gap Case $\left(\gamma=\mathrm{c}_{\mathrm{H}} / \mathrm{c}_{\mathrm{L}}<5 / 3\right)$

In this case, the same behavior as in the large gap case constitutes as an equilibrium behavior. But the equilibrium is not unique for the intermediate values of $I$. More specifically, in this case there exists a set $m=\left[\frac{(3 \gamma-2) c_{L}}{6 \gamma}, \frac{c_{L}}{2 \gamma}\right]$ which is contained in $\boldsymbol{M}$ 
( $m \subset \boldsymbol{M}$ ). If $I \in \boldsymbol{m}$, there are two additional equilibria, one in pure strategies where only the high cost firm invests and another in mixed strategies where the low cost firm invests with probability $\frac{3\left(c_{L}-2 \gamma I\right)}{2 c_{L}}$ and the high cost firm invests with probability $\frac{3 \gamma\left(c_{L}-2 I\right)}{2 c_{L}}$.

\section{A.2. Bundling}

Once again, let me make the assumption that $\mathrm{s}_{\mathrm{A}}=\mathrm{v}_{\mathrm{A}}-\mathrm{c}_{\mathrm{A}}$ is sufficiently large that $\mathrm{x}_{1}$ $-\mathrm{s}_{\mathrm{A}}$ is always less than $\mathrm{x}_{2}$. Then, firm 2 has no incentive to invest in R\&D since it knows that it will be completely foreclosed from market B. Given this fact, the tying firm will invest in $\mathrm{R} \& \mathrm{D}$ if and only if $I$ is less than $\mathrm{c}_{\mathrm{B} 1} / 2$, which is the expected cost saving from R\&D.

Proposition A2. With bundling, the rival firm has no incentive to engage in R\&D whereas the tying firm engages in $R \& D$ if its expected cost saving from $R \& D$ outweighs the cost of $\mathrm{R} \& \mathrm{D}$ investment $\left(I<\mathrm{c}_{\mathrm{B} 1} / 2\right)$.

For the analysis of the first-best socially optimal configuration of R\&D decisions, I first note that if only one firm is to invest in $R \& D$, it should be the low cost firm for efficiency. This follows from the assumption of experience effects in the R\&D process. Thus, we can consider three possible configurations of $R \& D$ investment. If both firms invest in $R \& D$, the expected total cost of product $\mathrm{B}$ is given by $\mathrm{E}[\mathrm{Min}(\mathrm{x}, \mathrm{y})]+2 I$, where $\mathrm{x}$ is uniformly distributed on $\left[0, c_{L}\right]$ and $y$ is uniformly distributed on $\left[0, c_{H}\right]$. If only the low cost firm invests in $\mathrm{R} \& \mathrm{D}$, the expected total cost is $\mathrm{E}[\mathrm{x}]+I$. Finally, if nobody invests in $\mathrm{R} \& \mathrm{D}$, the total cost is simply $c_{\mathrm{L}}$. This leads me to the following Proposition.

Proposition A3. The socially optimal configuration of R\&D investment is given by:

(i)If $I \in \boldsymbol{L}=\left[0, \frac{c_{L}}{6 \gamma}\right]$, both firms should invest in R\&D. 
(ii)If $I \in M=\left[\frac{c_{L}}{6 \gamma}, \frac{c_{L}}{2}\right]$, only the low cost firm should invest in R\&D.

(iii)If $I \in \boldsymbol{H}=\left[\frac{c_{L}}{6 \gamma}, \infty\right)$, neither firm should invest in R\&D.

The comparison of Propositions A1-A3 reveals that the private R\&D incentives are more closely aligned with the socially optimal incentives under bundling when the cost asymmetry is taken into account. The social incentives and private incentives coincide without bundling in the case of large efficiency gap, and also in the small efficiency gap case to the extent that the equilibrium with the low cost firm investing is chosen in the case of multiple equilibria parameter region. Thus, bundling will distort efficiency in R\&D decision if it changes the incentives.

With the knowledge in hand of how the R\&D competition and the price competition play out under bundling and non-bundling, I can now analyze the incentive to bundle for firm 1. I consider two cases depending on whether or not the monopolistic supplier of product A is also initially more efficient supplier of product B.

1. Firm 1 is initially more efficient than firm 2 in market $\mathrm{B}\left(\mathrm{c}_{\mathrm{B} 1}<\mathrm{c}_{\mathrm{B} 2}\right)$

In this case, it has been shown that bundling has no (harmful) effect on the tying firm's profits without $R \& D$ considerations. Since bundling eliminates the incentives to invest in $\mathrm{R} \& \mathrm{D}$ for the rival firm, bundling will guarantee that the tying firm maintains a cost advantage in market B. Thus, there is no adverse effect of bundling from the price competition. The only effect from bundling is to reduce the R\&D incentives of the rival firm. I can conclude that firm 1 always has the incentive to bundle if it has an initial cost advantage in product $B$. 
2. Firm 1 is initially less efficient than firm 2 in market $B\left(c_{B 1}>c_{B 2}\right)$

In this case, it is still possible that the tying firm turns out to have a higher production cost even after it invests in R\&D while the rival firm did not. Thus, the monopolistic supplier of $\mathrm{A}$ has to consider the negative consequences of price competition in its bundling decision. Only when the beneficial effects of bundling in capturing dynamic rents outweighs the negative effects of price competition, it will bundle. Moreover, the portion of $R \& D$ benefits in cost reduction used to catch up with the rival firm's cost, which is $(\gamma-1)$ does not contribute to the net profit. Thus, firm 1 will choose to bundle only when its initial cost disadvantage is not sufficiently large. A straightforward calculation of firm 1's profits under bundling and nonbundling yields the result that firm 1 chooses to bundle if and only if $\gamma=\frac{c_{B 1}}{c_{B 2}}<1+\sqrt{\frac{2}{3}}$.

Proposition A4. If $I \in \boldsymbol{L} \cup \boldsymbol{M}$ and $\frac{c_{B 1}}{c_{B 2}}<1+\sqrt{\frac{2}{3}}$, firm 1 (weakly) prefers to bundle. If $I \in \boldsymbol{L}$, bundling unambiguously reduces welfare by eliminating the R\&D incentives of the rival firm. If $I \in \boldsymbol{M}$, there are two cases to consider.

Case 1. $\mathrm{c}_{\mathrm{B} 1}<\mathrm{c}_{\mathrm{B} 2}$

If $\gamma=\frac{c_{B 2}}{c_{B 1}}<5 / 3$, bundling can increase welfare by serving as a coordinating mechanism in the $\mathrm{R} \& \mathrm{D}$ game.

$\underline{\text { Case 2. }} \mathrm{c}_{\mathrm{B} 1}>\mathrm{c}_{\mathrm{B} 2}$

If $5 / 3<\gamma=\frac{c_{B 1}}{c_{B 2}}<1+\sqrt{\frac{2}{3}}$, bundling reduces welfare by inducing the less efficient firm to invest in $R \& D$ at the expense of $R \& D$ investment by the more efficient firm. 
If $\gamma=\frac{c_{B 1}}{c_{B 2}}<5 / 3$, the welfare consequences of bundling depends on the selection of equilibrium under nonbundling. If the equilibrium is the one in which only the more efficient rival firm invests in $R \& D$, bundling reduces welfare. However, the mixed strategy equilibrium is played, bundling partially solves a coordination failure problem and improves welfare. 


\title{
CESifo Working Paper Series
}

\author{
(for full list see www.cesifo.de)
}

1273 Assaf Razin and Efraim Sadka, Welfare Migration: Is the Net Fiscal Burden a Good Measure of its Economics Impact on the Welfare of the Native-Born Population?, September 2004

1274 Tomer Blumkin and Volker Grossmann, Ideological Polarization, Sticky Information, and Policy Reforms, September 2004

1275 Katherine Baicker and Nora Gordon, The Effect of Mandated State Education Spending on Total Local Resources, September 2004

1276 Gabriel J. Felbermayr and Wilhelm Kohler, Exploring the Intensive and Extensive Margins of World Trade, September 2004

1277 John Burbidge, Katherine Cuff and John Leach, Capital Tax Competition with Heterogeneous Firms and Agglomeration Effects, September 2004

1278 Joern-Steffen Pischke, Labor Market Institutions, Wages and Investment, September 2004

1279 Josef Falkinger and Volker Grossmann, Institutions and Development: The Interaction between Trade Regime and Political System, September 2004

1280 Paolo Surico, Inflation Targeting and Nonlinear Policy Rules: The Case of Asymmetric Preferences, September 2004

1281 Ayal Kimhi, Growth, Inequality and Labor Markets in LDCs: A Survey, September 2004

1282 Robert Dur and Amihai Glazer, Optimal Incentive Contracts for a Worker who Envies his Boss, September 2004

1283 Klaus Abberger, Nonparametric Regression and the Detection of Turning Points in the Ifo Business Climate, September 2004

1284 Werner Güth and Rupert Sausgruber, Tax Morale and Optimal Taxation, September 2004

1285 Luis H. R. Alvarez and Erkki Koskela, Does Risk Aversion Accelerate Optimal Forest Rotation under Uncertainty?, September 2004

1286 Giorgio Brunello and Maria De Paola, Market Failures and the Under-Provision of Training, September 2004

1287 Sanjeev Goyal, Marco van der Leij and José Luis Moraga-González, Economics: An Emerging Small World?, September 2004 
1288 Sandro Maffei, Nikolai Raabe and Heinrich W. Ursprung, Political Repression and Child Labor: Theory and Empirical Evidence, September 2004

1289 Georg Götz and Klaus Gugler, Market Concentration and Product Variety under Spatial Competition: Evidence from Retail Gasoline, September 2004

1290 Jonathan Temple and Ludger Wößmann, Dualism and Cross-Country Growth Regressions, September 2004

1291 Ravi Kanbur, Jukka Pirttilä and Matti Tuomala, Non-Welfarist Optimal Taxation and Behavioral Public Economics, October 2004

1292 Maarten C. W. Janssen, José Luis Moraga-González and Matthijs R. Wildenbeest, Consumer Search and Oligopolistic Pricing: An Empirical Investigation, October 2004

1293 Kira Börner and Christa Hainz, The Political Economy of Corruption and the Role of Financial Institutions, October 2004

1294 Christoph A. Schaltegger and Lars P. Feld, Do Large Cabinets Favor Large Governments? Evidence from Swiss Sub-Federal Jurisdictions, October 2004

1295 Marc-Andreas Mündler, The Existence of Informationally Efficient Markets When Individuals Are Rational, October 2004

1296 Hendrik Jürges, Wolfram F. Richter and Kerstin Schneider, Teacher Quality and Incentives: Theoretical and Empirical Effects of Standards on Teacher Quality, October 2004

1297 David S. Evans and Michael Salinger, An Empirical Analysis of Bundling and Tying: Over-the-Counter Pain Relief and Cold Medicines, October 2004

1298 Gershon Ben-Shakhar, Gary Bornstein, Astrid Hopfensitz and Frans van Winden, Reciprocity and Emotions: Arousal, Self-Reports, and Expectations, October 2004

1299 B. Zorina Khan and Kenneth L. Sokoloff, Institutions and Technological Innovation During Early Economic Growth: Evidence from the Great Inventors of the United States, 1790 - 1930, October 2004

1300 Piero Gottardi and Roberto Serrano, Market Power and Information Revelation in Dynamic Trading, October 2004

1301 Alan V. Deardorff, Who Makes the Rules of Globalization?, October 2004

1302 Sheilagh Ogilvie, The Use and Abuse of Trust: Social Capital and its Deployment by Early Modern Guilds, October 2004

1303 Mario Jametti and Thomas von Ungern-Sternberg, Disaster Insurance or a Disastrous Insurance - Natural Disaster Insurance in France, October 2004 
1304 Pieter A. Gautier and José Luis Moraga-González, Strategic Wage Setting and Coordination Frictions with Multiple Applications, October 2004

1305 Julia Darby, Anton Muscatelli and Graeme Roy, Fiscal Federalism, Fiscal Consolidations and Cuts in Central Government Grants: Evidence from an Event Study, October 2004

1306 Michael Waldman, Antitrust Perspectives for Durable-Goods Markets, October 2004

1307 Josef Honerkamp, Stefan Moog and Bernd Raffelhüschen, Earlier or Later: A General Equilibrium Analysis of Bringing Forward an Already Announced Tax Reform, October 2004

1308 M. Hashem Pesaran, A Pair-Wise Approach to Testing for Output and Growth Convergence, October 2004

1309 John Bishop and Ferran Mane, Educational Reform and Disadvantaged Students: Are They Better Off or Worse Off?, October 2004

1310 Alfredo Schclarek, Consumption and Keynesian Fiscal Policy, October 2004

1311 Wolfram F. Richter, Efficiency Effects of Tax Deductions for Work-Related Expenses, October 2004

1312 Franco Mariuzzo, Patrick Paul Walsh and Ciara Whelan, EU Merger Control in Differentiated Product Industries, October 2004

1313 Kurt Schmidheiny, Income Segregation and Local Progressive Taxation: Empirical Evidence from Switzerland, October 2004

1314 David S. Evans, Andrei Hagiu and Richard Schmalensee, A Survey of the Economic Role of Software Platforms in Computer-Based Industries, October 2004

1315 Frank Riedel and Elmar Wolfstetter, Immediate Demand Reduction in Simultaneous Ascending Bid Auctions, October 2004

1316 Patricia Crifo and Jean-Louis Rullière, Incentives and Anonymity Principle: Crowding Out Toward Users, October 2004

1317 Attila Ambrus and Rossella Argenziano, Network Markets and Consumers Coordination, October 2004

1318 Margarita Katsimi and Thomas Moutos, Monopoly, Inequality and Redistribution Via the Public Provision of Private Goods, October 2004

1319 Jens Josephson and Karl Wärneryd, Long-Run Selection and the Work Ethic, October 2004

1320 Jan K. Brueckner and Oleg Smirnov, Workings of the Melting Pot: Social Networks and the Evolution of Population Attributes, October 2004 
1321 Thomas Fuchs and Ludger Wößmann, Computers and Student Learning: Bivariate and Multivariate Evidence on the Availability and Use of Computers at Home and at School, November 2004

1322 Alberto Bisin, Piero Gottardi and Adriano A. Rampini, Managerial Hedging and Portfolio Monitoring, November 2004

1323 Cecilia García-Peñalosa and Jean-François Wen, Redistribution and Occupational Choice in a Schumpeterian Growth Model, November 2004

1324 William Martin and Robert Rowthorn, Will Stability Last?, November 2004

1325 Jianpei Li and Elmar Wolfstetter, Partnership Dissolution, Complementarity, and Investment Incentives, November 2004

1326 Hans Fehr, Sabine Jokisch and Laurence J. Kotlikoff, Fertility, Mortality, and the Developed World's Demographic Transition, November 2004

1327 Adam Elbourne and Jakob de Haan, Asymmetric Monetary Transmission in EMU: The Robustness of VAR Conclusions and Cecchetti's Legal Family Theory, November 2004

1328 Karel-Jan Alsem, Steven Brakman, Lex Hoogduin and Gerard Kuper, The Impact of Newspapers on Consumer Confidence: Does Spin Bias Exist?, November 2004

1329 Chiona Balfoussia and Mike Wickens, Macroeconomic Sources of Risk in the Term Structure, November 2004

1330 Ludger Wößmann, The Effect Heterogeneity of Central Exams: Evidence from TIMSS, TIMSS-Repeat and PISA, November 2004

1331 M. Hashem Pesaran, Estimation and Inference in Large Heterogeneous Panels with a Multifactor Error Structure, November 2004

1332 Maarten C. W. Janssen, José Luis Moraga-González and Matthijs R. Wildenbeest, A Note on Costly Sequential Search and Oligopoly Pricing, November 2004

1333 Martin Peitz and Patrick Waelbroeck, An Economist's Guide to Digital Music, November 2004

1334 Biswa N. Bhattacharyay and Prabir De, Promotion of Trade, Investment and Infrastructure Development between China and India: The Case of Southwest China and East and Northeast India, November 2004

1335 Lutz Hendricks, Why Does Educational Attainment Differ Across U.S. States?, November 2004

1336 Jay Pil Choi, Antitrust Analysis of Tying Arrangements, November 2004 